\title{
SALINE-ALKALINE SOIL BACTERIAL COMMUNITY STRUCTURE AND DIVERSITY ANALYSIS UNDER DIFFERENT PATTERNS OF LAND-USE IN A LAKE WETLAND IN SONGNEN PLAIN, CHINA
}

\author{
SHI, C. Q. ${ }^{1,2}-\mathrm{LI}, \mathrm{Y}^{3}-\mathrm{YU}, \mathrm{S} . \mathrm{P}{ }^{*}{ }^{*}-\mathrm{HU}$, B. Z. ${ }^{1,2}-$ GUO, H. ${ }^{1}-$ JIN, L. ${ }^{4}-$ CONG, D. L. ${ }^{1}-$ MENG, B. \\ - DING, J. N. ${ }^{1}-$ LIANG, X. W. ${ }^{1}$ \\ ${ }^{1}$ Heilongjiang Province Key Laboratory of Cold Region Wetland Ecology and Environment \\ Research, Harbin University, Harbin 150086, Heilongjiang Province, P. R. China \\ ${ }^{2}$ College of Life Science, Northeast Agricultural University, Harbin 150038, Heilongjiang \\ Province, P. R. China \\ ${ }^{3}$ College of Resource and Environment, Northeast Agricultural University, Harbin 150038, \\ Heilongjiang Province, P. R. China \\ ${ }^{4}$ Plant Nutriention and Resources Institute, Beijing Academy of Agriculture and Forestry \\ Sciences, Beijing 100097, Heilongjiang Province, P. R. China \\ ${ }^{*}$ Corresponding author \\ e-mail: wetlands1972@126.com; phone: +86-0451-8662-3372 \\ (Received $5^{\text {th }}$ Nov 2020; accepted $8^{\text {th }}$ Feb 2021)
}

\begin{abstract}
In this study, the saline-alkaline soil samples were collected from Gudahu Wetland in Songnen Plain, China, in May (dry season) and July (rainy season), 2018. The soil bacterial community structure and diversity in the original meadow, lake dam, cropland, and woodland were analyzed using high-throughput sequencing technology. The results showed that Proteobacteria were the dominant bacterial phylum during the two seasons. Except for an unclassified group at the generic level, Pseudomonas showed the highest relative abundance. The lake dam's soil bacterial community diversity was the lowest, followed by the original meadow, while those of cropland and woodland were higher. The soil bacterial community structures differed among the four land-use patterns. Cropland and woodland showed the highest differences in soil bacterial community structure compared to the original meadow than the lake dam. In contrast to cropland and woodland, soil bulk density, electrical conductivity, and $\mathrm{pH}$ had a higher impact on the bacterial community diversities of the original meadow and the lake dam. Dam construction, cultivation, and afforestation in the saline-alkaline lake wetland of Songnen Plain changed the physicochemical properties of soil from the original meadow. It affected the bacterial community structure and diversity.
\end{abstract}

Keywords: soil microbe, high-throughput sequencing, saline-alkaline wetland, seasonal changes

\section{Introduction}

Soil alkalization or salinization is a type of soil degradation, which poses a severe threat to ecosystems across the globe since it adversely affects plant growth and microbial function (Yan et al., 2015; Liu et al., 2016). The total area of saline land has reached 950 million ha of land worldwide (Zhang et al., 2005). Songnen Plain in northeast China is one of the three largest sodic-saline areas globally due to significant alkalization of soil, and > 3.2 million ha land is affected by high salt content (Bian et al., 2008; Wang et al., 2009). The primary factors causing soil salinization and alkalization are a) natural environmental factors, such as geology and geomorphology, soil matrix, climate, hydrology and rainfall, and b) human interferences, such as road construction, 
embankment construction, reservoir engineering, and overgrazing. Soil degradation, has adverse effects on the ecological environment, agriculture, and husbandry; it degenerates a large grassland area (Shang et al., 2003; Wan et al., 2003; Wang et al., 2009; Zhou et al., 2011).

Soil microbiota is a crucial component of the ecosystem, which participates in distinct ecological processes, such as organic matter decomposition, nutrient transformation, and pollutant degradation (Foti et al., 2007; Griffiths and Laurent, 2013; Zhao et al., 2015). Environmental changes influence the community structure and diversity of soil microbiota, and they serve as an indicator of soil's ecological environment (Hansel et al., 2008; Canfora et al., 2014; Zhang et al., 2018; Liu et al., 2020). Multiple environmental factors, such as land-use patterns (Peng et al., 2017), vegetation types (Zak et al., 2003; Jin et al., 2017; Deng et al., 2018; Li et al., 2018a), and soil nutrient condition (Li et al., 2018b) influences the diversity of soil microbiota. Several physicochemical factors, such as $\mathrm{pH}$, soil electrical conductivity (EC), soil moisture, and so on, also play crucial roles in deriving the diversity of microbial community structure. Microbial diversity is affected by $\mathrm{pH}$ (Shen et al., 2013; Li et al., 2018c; Fan and $\mathrm{Wu}, 2020$ ) as a high $\mathrm{pH}$ substantially mitigates the microbial growth, culminating in decreased diversity of microbial community (Zhang and Feng, 2008; Chu et al., 2017). Apart from pH, soil's EC is also a crucial physicochemical component that influences microbial activity, biomass, and community structure (Yan et al., 2015). EC also alters bacterial community structure under alkaline conditions in saline-alkaline soil (Wang et al., 2020). Soil moisture affects oxygen content and regulates the type, activity, and growth of microbes (Yan et al., 2015; Zhang et al., 2016; Zou et al., 2018), substantially influencing the microbial community structure.

The soil nutrient content, permeability of saline-alkaline wetland soil, and soil microbes' diversity are also low (Niu et al., 2017). However, only a few studies have explored the structure and diversity of soil microbial communities in saline-alkaline wetland environment (Gandhi et al., 2018), particularly in different seasons and landuse conditions. Systematic analysis of soil microbial community structure dynamics and diversity could provide significant data for wetland protection in different seasons. The Gudahu Wetland is a typical representative of the permanent saline lake in the Songnen Plain lake wetland, where artificial interferences pose a significant threat to the soil environment. In this study, the saline-alkaline soils in different land-use patterns of the Gudahu Wetland were analyzed. A total of 24 soil samples were collected during May and July, 2018, and analyzed using high-throughput sequencing technology to elucidate the structure and diversity of the soil microbial community and associated influencing factors. The objective of this study was i) to reveal the characteristics of the soil microbial community in saline-alkaline wetland, and ii) to provide scientific data for studying microbial biodiversity in the saline-alkaline wetland in the cold and arid areas of northeast China. Additionally, reference and theoretical guidance for the protection and rational utilization of saline-alkaline wetland and strategies for returning farmland to wetland were suggested in this study.

\section{Materials and methods}

\section{Study area description}

Gudahu Wetland is located in the middle of Songnen Plain, Anda City, Heilongjiang Province, China. It occupies a total of $4,850.1$ ha area, which is $8.2 \mathrm{~km}$ long (south to 
north $46^{\circ} 19^{\prime} 31^{\prime \prime}-46^{\circ} 23^{\prime} 58^{\prime \prime} \mathrm{N}$ ), and $8 \mathrm{~km}$ wide (west to east $125^{\circ} 28^{\prime} 06^{\prime \prime}-125^{\circ} 34^{\prime} 34^{\prime \prime} \mathrm{E}$ ), This wetland has a continental monsoon climate, and it experiences low annual rainfall and high evaporation rate. In this wetland, spring and autumn seasons are accompanied by frequent strong winds, summers with torridity, and winters with cold-dry weather. The annual average temperature is $3.2^{\circ} \mathrm{C}$. Under such climatic conditions, most plants start growing in May and flourish in July. Gudahu Wetland is a typical inland plain and permanently saline lake wetland, and it includes most of the Qingken Lake area, and herbaceous swamp and marshy meadow, with a $99.1 \%$ wetland rate. This region is surrounded by cropland and woodland.

\section{Soil sample collection}

Soil samples were collected from the original meadow (O), lake dam (L), cropland (C), and woodland (W) on May 30, 2018 (dry season) and July 30, 2018 (rainy season). Three quadrats were set for each soil type. $200 \mathrm{~g}$ soil was sampled from four vertices and center points at a depth of $5-10 \mathrm{~cm}$ below the ground surface, each quadrat $(20 \mathrm{~m} \times 20 \mathrm{~m})$ using a ring knife $(\Phi=4 \mathrm{~cm})$. The impurities from the soil samples were removed, and purified samples were thoroughly mixed. $50 \mathrm{~g}$ portion of the soil sample was retained, and $2 \mathrm{~g}$ was put into an appropriately labeled tube containing microbial DNA preservation solution (TinyGene, Shanghai, China). The remaining soil was used for physicochemical analysis at low temperatures $\left(-20^{\circ} \mathrm{C}\right)$ at the laboratory. The geographical coordinates, altitude, and dominant plant species in the sampling area were recorded (Table 1).

Table 1. Details of soil samples collected in Gudahu Wetland in Songnen Plain, China

\begin{tabular}{|c|c|c|c|c|c|c|}
\hline Type & Sample & Longitude & Latitude & Altitude & $\begin{array}{c}\text { Dominant plants in } \\
\text { May }\end{array}$ & Dominant plants in July \\
\hline \multirow{3}{*}{$\mathbf{O}$} & 01 & $125^{\circ} 28^{\prime} 17.34^{\prime \prime}$ & $46^{\circ} 20^{\prime} 30.42^{\prime \prime} \mathrm{N}$ & $149.4 \mathrm{~m}$ & \multirow{3}{*}{$\begin{array}{c}\text { Suaeda glauca, } \\
\text { Puccinellia tenuiflora, } \\
\text { Kochia scoparia }\end{array}$} & \multirow{3}{*}{$\begin{array}{l}\text { Artemisia anethifolia, } \\
\text { Suaeda glauca, Kochia } \\
\text { scoparia }\end{array}$} \\
\hline & $\mathbf{O 2}$ & $125^{\circ} 34^{\prime} 09.18^{\prime \prime}$ & & 144. & & \\
\hline & $\mathbf{O 3}$ & $125^{\circ} 32 ' 27.41^{\prime \prime}$ & & $148.2 \mathrm{~m}$ & & \\
\hline \multirow{3}{*}{$\mathbf{L}$} & L1 & $125^{\circ} 29^{\prime} 02.95^{\prime \prime}$ & $46^{\circ} 23^{\prime} 09.05^{\prime \prime} \mathrm{N}$ & $142.9 \mathrm{~m}$ & \multirow{3}{*}{$\begin{array}{l}\text { Phragmites australis, } \\
\text { Artemisia selengensis, } \\
\text { Chenopodium album, } \\
\text { Ixeris chinensis }\end{array}$} & \multirow{3}{*}{$\begin{array}{c}\text { Phragmites australis, } \\
\text { Artemisia selengensis, Aster } \\
\text { pekinensis, Setaria viridis, } \\
\text { Plantago asiatica }\end{array}$} \\
\hline & $\mathbf{L 2}$ & $125^{\circ} 29^{\prime} 45.57^{\prime \prime}$ & $46^{\circ} 23^{\prime} 50$ & $146.3 \mathrm{~m}$ & & \\
\hline & $\mathbf{L 3}$ & $125^{\circ} 30^{\prime} 26.90^{\prime \prime}$ & $46^{\circ} 23^{\prime} 56.60^{\prime \prime} \mathrm{N}$ & $143.6 \mathrm{~m}$ & & \\
\hline & C1 & $125^{\circ} 28^{\prime} 56.66^{\prime \prime}$ & $46^{\circ} 23^{\prime} 20.79^{\prime \prime} \mathrm{N}$ & $145.5 \mathrm{~m}$ & \multirow{3}{*}{$\begin{array}{c}\text { Zea mays, Equisetum } \\
\text { arvense }\end{array}$} & \multirow{3}{*}{$\begin{array}{c}\text { Zea mays, Solanum nigrum, } \\
\text { Echinochloa crus-galli, } \\
\text { Amethystea caerulea }\end{array}$} \\
\hline & $\mathrm{C} 2$ & $125^{\circ} 27^{\prime} 59.95^{\prime \prime}$ & $46^{\circ} 22^{\prime} 33.69^{\prime \prime} \mathrm{N}$ & $144.3 \mathrm{~m}$ & & \\
\hline & $\mathbf{C 3}$ & $125^{\circ} 27^{\prime} 43.59^{\prime \prime}$ & $46^{\circ} 22^{\prime} 11.95^{\prime \prime} \mathrm{N}$ & & & \\
\hline \multirow{4}{*}{$\mathbf{W}$} & W1 & $125^{\circ} 28^{\prime} 56.42^{\prime \prime}$ & $46^{\circ} 23^{\prime} 33.93^{\prime \prime} \mathrm{N}$ & $152.0 \mathrm{~m}$ & \multirow{4}{*}{$\begin{array}{l}\text { Populus simonii, Leymus } \\
\text { chinensis, Potentilla } \\
\text { chinensis, Artemisia } \\
\text { scoparia, Kochia } \\
\text { scoparia, Chloris virgata }\end{array}$} & \multirow{4}{*}{$\begin{array}{c}\text { Populus simonii, Leymus } \\
\text { chinensis, Potentilla } \\
\text { chinensis, Artemisia } \\
\text { scoparia, Kochia scoparia, } \\
\text { Digitaria ciliaris var. } \\
\text { chrysoblephara }\end{array}$} \\
\hline & W2 & $125^{\circ} 30^{\prime} 16.64^{\prime \prime}$ & $46^{\circ} 23^{\prime} 57.24^{\prime \prime} \mathrm{N}$ & $157.5 \mathrm{~m}$ & & \\
\hline & & & & 1547 & & \\
\hline & W3 & 1253142.9 & $446^{\circ} 2353.22^{2} \mathrm{~N}$ & $154.1 \mathrm{~m}$ & & \\
\hline
\end{tabular}

Note: O (original meadow), L (lake dam), C (cropland), and W (woodland) were the four land-use patterns in Gudahu Wetland in Songnen Plain, China. Identical soil samples were collected from the same location during May and July, 2018. The identification of dominant plant species was based on the "Flora of China" (Wu et al., 2013)

\section{Determination of soil's physicochemical properties}

The physicochemical properties of 24 soil samples were determined as described previously by Bao (2007) and Yu et al. (2020). Ring knife $(\Phi=4 \mathrm{~cm})$ method was used 
to determine soil bulk density (BD), drying method $\left(105^{\circ} \mathrm{C}\right)$ for soil moisture $(\mathrm{M})$, electrical conductivity meter (DDS-307A, RER, Shanghai) method for soil EC, pH meter (INESA PHS-3C, Shanghai) method for soil pH, TOC analyzer (Multi N/C2100, Analytik-Jena, Germany) method for total organic carbon (TOC), Semi-Micro Kjeldahl Method for total N (TN), alkaline hydrolysis diffusion method for available N (AN), $\mathrm{Mo}-\mathrm{Sb}$ anti spectrophotometric method for total P (TP) and available P (AP), flame photometer method for total K (TK) and available K (AK), were used. Each index was measured three times.

\section{Soil bacteria genomic DNA extraction and PCR amplification}

Bacterial DNA was extracted using the MIO-BIO Power Soil DNA Isolation Kit (QIAGEN, Germany), as per manufacture's instructions. Specific primers (515F 5'-GTGCCAGCMGCCGCGGTAA-3' and 926R 5'-CCGTCAATTCMTTTGAGTT-3') were used to amplify the $16 \mathrm{~S}$ rRNA V4-V5 region of the soil bacteria. Amplicon sequencing was performed using the Illumina MiSeq platform at TinyGene Technologies, Inc. (Shanghai, China).

\section{Statistical analysis}

The pair-end reads obtained from DNA of bacterial soil samples were distinguished using barcode. To extract effective sequences, all the sequences were quality controlled and filtered as described previously by Liu et al. (2012) and Zhao et al. (2018). All data were submitted into the NCBI Sequence Read Archive database (Accession number: PRJNA615241). The effective sequences were merged based on the overlaps and subsequently quality controlled and filtered to obtain the optimized sequences of soil bacteria. The relative abundance information of each OTU in each sample was computed using the UPARSE pipeline (Edgar, 2013) to cluster the optimized sequences into operational taxonomic units (OTUs) at 97\% similarity. QIIME (version 1.8.0) software (Caporaso et al., 2010) was used to analyze factors representing the diversity of the bacterial community in each sample, including the Chao1 and Shannon index and rarefaction curves. Venn diagrams were drawn using the VennDiagram package version 1.6.20 (Chen, 2018) in $\mathrm{R}$ (version 3.4.1) software ( $\mathrm{R}$ Core Team, 2017). Histograms depicting the community structure at the phyletic and generic levels of relative abundance were generated using Office Excel 2010. The pheatmap package version 1.0.12 (Kolde, 2019) in R (v3.4.1) software ( $\mathrm{R}$ Core Team, 2017) analyzed and displayed the bacterial community similarity at the OTU level based on the unweighted UniFrac algorithm. The correlation between the bacterial communities and soil's physicochemical properties were analyzed using Canoco for Windows (version 4.54) software with the redundancy analysis (RDA) method. Monte Carlo permutation tests were used to determine significance (number of permutations=999). CanoDraw for Windows (version 4.13) was used for drawing. SPSS Statistics for Windows (version 17.0, SPSS Inc. Chicago, IL, USA) was used to test the differences in physicochemical properties, the richness and diversity indexes of bacterial communities and the relative abundance of dominant phyla using Duncan's multiple range test and t-test $(P<0.05$ represent significant difference and $P<0.01$ represent very significant difference), also, to analyze the correlation between the dominant bacterial phyla and soil's physicochemical properties using Pearson correlation analysis $(P<0.05$ represent significant correlation and $P<0.01$ represent very significant correlation). 


\section{Results}

\section{Physicochemical properties of soil}

Out of all the land-use patterns, the BD of $\mathrm{L}$ was the highest due to the compaction of lake dam soil (Table 2), and that of $\mathrm{C}$ was the lowest due to plowing. The $\mathrm{M}$ of $\mathrm{C}$ was the highest in May. $\mathrm{M}$ of $\mathrm{L}$ and $\mathrm{C}$ either increased significantly $(P<0.05)$ in July. The EC of $\mathrm{W}$ was lowest, and the EC of $\mathrm{L}$ and $\mathrm{C}$ showed a significant $(P<0.05)$ decrease in July. The $\mathrm{pH}$ for each soil type was higher than 7 , and the $\mathrm{pH}$ of $\mathrm{O}$ was the highest. The $\mathrm{pH}$ of L increased significantly $(P<0.05)$ in July, and that for $\mathrm{C}$ decreased significantly $(P<0.05)$. Due to fertilization, the contents of soil nutrients (TOC, TN, $\mathrm{TK}$, and so on) in $\mathrm{C}$ were significantly $(P<0.05)$ higher than those of $\mathrm{W}, \mathrm{L}$, and $\mathrm{O}$. The changes in the contents of $\mathrm{C}$ and $\mathrm{W}$ soil nutrients were more significant in July than $\mathrm{L}$ and $\mathrm{O}$.

Table 2. Physicochemical properties of soil in Gudahu Wetland in Songnen Plain, China in May and July

\begin{tabular}{|c|c|c|c|c|c|c|c|c|}
\hline \multirow{2}{*}{ Index } & \multicolumn{4}{|c|}{ May } & \multicolumn{4}{|c|}{ July } \\
\hline & O & L & C & W & O & L & C & W \\
\hline BD & $1.48 \pm 0.05$ & $1.87 \pm 0.07$ & $1.04 \pm 0.10$ & $1.38 \pm 0.03$ & $1.47 \pm 0.06$ & $1.93 \pm 0.05$ & $1.22 \pm 0.06$ & $1.41 \pm 0.05$ \\
\hline & $\mathrm{bB}$ & $\mathrm{aA}$ & $\mathrm{cC}$ & & bB & $\mathrm{aA}$ & $\mathrm{cC}$ & \\
\hline M & $13.09 \pm 1.53$ & $16.32 \pm 1.09$ & $22.60 \pm 1.92$ & $13.33 \pm 2$ & $16.50 \pm 1.95$ & $23.85 \pm 1.43$ & $26.38 \pm 1.08$ & $18.52 \pm 2$ \\
\hline$(\%)$ & $\mathrm{bB}$ & $\mathrm{bB}^{* *}$ & $\mathrm{aA}^{*}$ & & $\mathrm{bB}$ & & & \\
\hline $\begin{array}{c}\text { EC } \\
(\mathrm{ms} / \mathrm{cm}\end{array}$ & $\begin{array}{c}3.43 \pm 0.79 \\
\mathrm{bAB}\end{array}$ & $\begin{array}{r}4.61 \pm \\
\mathrm{abA}\end{array}$ & $\begin{array}{r}5.28 \pm 0 \\
\mathrm{aA}\end{array}$ & $\begin{array}{c}1.77 \pm 0.56 \\
\mathrm{cB}\end{array}$ & $\begin{array}{c}3.64 \pm 0.60 \\
\mathrm{aA}\end{array}$ & $\begin{array}{r}2.21 \pm \\
\mathrm{bcA}\end{array}$ & & $\begin{array}{c}1.56 \pm 0.4 \\
\mathrm{cB}\end{array}$ \\
\hline pH & $\begin{array}{c}9.12 \pm 0.11 \\
\mathrm{aA}\end{array}$ & $\begin{array}{c}8.14 \pm 0.10 \\
b^{*}\end{array}$ & $\begin{array}{c}8.00 \pm 0.15 \\
\mathrm{bB}^{*}\end{array}$ & $\begin{array}{c}8.15 \pm 0 . \\
\text { bB }\end{array}$ & $\begin{array}{c}9.09 \pm 0.10 \\
\mathrm{aA}\end{array}$ & $\begin{array}{c}8.48 \pm 0.13 \\
\mathrm{bB}^{*}\end{array}$ & $\begin{array}{c}7.69 \pm 0.11 \\
\mathrm{cC}^{*}\end{array}$ & 0.15 \\
\hline $\begin{array}{c}\text { TOC } \\
(\mathrm{g} / \mathrm{kg})\end{array}$ & $\begin{array}{c}3.51 \pm 0.19 \\
\mathrm{dD}\end{array}$ & $\begin{array}{c}7.78 \pm 0.65 \\
\mathrm{cC}\end{array}$ & $\begin{array}{c}24.18 \pm 2.10 \\
\mathrm{aA}^{*}\end{array}$ & $\begin{array}{r}16.2 \\
\mathrm{~b}\end{array}$ & $\begin{array}{r}3.84 \pm 0 . \\
\mathrm{dC}\end{array}$ & $\begin{array}{c}7.37 \pm 0.34 \\
\mathrm{cC}\end{array}$ & $\begin{array}{r}33.76= \\
\mathrm{aA}\end{array}$ & $\begin{array}{r}24.61 \\
\mathrm{bB}\end{array}$ \\
\hline $\begin{array}{c}\text { TN } \\
(\mathrm{g} / \mathrm{kg})\end{array}$ & $\begin{array}{c}0.68 \pm 0.02 \\
\mathrm{cC}^{* *}\end{array}$ & $\begin{array}{c}1.17 \pm 0.02 \\
\mathrm{bB}^{* *}\end{array}$ & $\begin{array}{c}2.24 \pm 0.15 \\
\mathrm{aA}^{* *}\end{array}$ & $\begin{array}{c}1.06 \pm 0.05 \\
\mathrm{bB}^{* *}\end{array}$ & $\begin{array}{c}1.02 \pm 0.06 \\
\mathrm{cC}^{* * *}\end{array}$ & $\begin{array}{c}0.89 \pm 0.03 \\
\mathrm{dD}^{* *}\end{array}$ & $\begin{array}{c}3.16 \pm 0.04 \\
\mathrm{aA}^{* *}\end{array}$ & $\begin{array}{c}2.68 \pm 0.05 \\
\mathrm{bB}^{* * *}\end{array}$ \\
\hline $\begin{array}{c}\mathrm{AN} \\
(\mathrm{mg} / \mathrm{kg})\end{array}$ & $\begin{array}{c}18.53 \pm 1.55 \\
\mathrm{dC}^{* * *}\end{array}$ & $\begin{array}{c}38.33 \pm 7.07 \\
\mathrm{cC}\end{array}$ & $\begin{array}{c}111.37 \pm 4.69 \\
\mathrm{aA}^{* * *}\end{array}$ & $\begin{array}{c}85.63 \pm 12.42 \\
b^{* * *}\end{array}$ & $\begin{array}{c}27.17 \pm 1.48 \\
\mathrm{cC}^{* *}\end{array}$ & $\begin{array}{c}50.96 \pm 5.14 \\
\text { bB }\end{array}$ & $\begin{array}{c}133.83 \pm 4.71 \\
\mathrm{aA}^{* * *}\end{array}$ & $\begin{array}{c}124.17 \pm 7.68 \\
\mathrm{aA}^{* * *}\end{array}$ \\
\hline$\underset{(\mathrm{g} / \mathrm{kg})}{\mathbf{T P}}$ & $\begin{array}{c}0.03 \pm 0.01 \\
\mathrm{bB}\end{array}$ & $\begin{array}{c}0.04 \pm 0.01 \\
\mathrm{bB}\end{array}$ & $\begin{array}{c}0.23 \pm 0.03 \\
\mathrm{aA}\end{array}$ & $\begin{array}{c}0.05 \pm 0.01 \\
\text { bB }\end{array}$ & $\begin{array}{c}0.02 \pm 0.01 \\
\mathrm{cB}\end{array}$ & $\begin{array}{c}0.05 \pm 0.01 \\
\mathrm{bB}\end{array}$ & $\begin{array}{c}0.25 \pm 0.03 \\
\mathrm{aA}\end{array}$ & $\begin{array}{c}0.06 \pm 0.01 \\
\mathrm{bB}\end{array}$ \\
\hline $\begin{array}{c}\mathbf{A P} \\
(\mathrm{mg} / \mathrm{kg})\end{array}$ & $\begin{array}{c}3.77 \pm 0.28 \\
\mathrm{cBC}^{* *}\end{array}$ & $\begin{array}{c}2.87 \pm 0.48 \\
\mathrm{cC}\end{array}$ & $\begin{array}{c}30.31 \pm 7.03 \\
\mathrm{aA}\end{array}$ & $\begin{array}{c}13.33 \pm 1.86 \\
b B\end{array}$ & $\begin{array}{c}5.14 \pm 0.18 \\
\mathrm{cC}^{* * *}\end{array}$ & $\begin{array}{c}3.11 \pm 0.03 \\
\mathrm{cC}\end{array}$ & $\begin{array}{c}42.08 \pm 3.91 \\
\mathrm{aA}\end{array}$ & $\begin{array}{c}15.05 \pm 2.02 \\
b B\end{array}$ \\
\hline TK & $\begin{array}{c}1.66 \pm 0.10 \\
\mathrm{cC}\end{array}$ & $\begin{array}{c}1.88 \pm 0.13 b \\
B C\end{array}$ & $\begin{array}{c}3.14 \pm 0.08 \\
\mathrm{aA}^{*}\end{array}$ & $\begin{array}{c}1.98 \pm 0.03 \\
\mathrm{bB}^{*}\end{array}$ & $\begin{array}{c}1.54 \pm 0.13 \\
\mathrm{dC}\end{array}$ & $\begin{array}{c}1.91 \pm 0.14 \\
\mathrm{cB}\end{array}$ & $\begin{array}{c}2.88 \pm 0.10 \\
\mathrm{aA}^{*}\end{array}$ & $\begin{array}{c}2.14 \pm 0.08 \\
\mathrm{bB}^{*}\end{array}$ \\
\hline AK & $122.49 \pm 9.12$ & $43.20 \pm 8.36$ & $265.27 \pm 8.4$ & $66.81 \pm 10$ & $37.28 \pm 11$ & $33.35 \pm 20$ & $327.72 \pm 14$ & $274.55 \pm 12$ \\
\hline$(\mathrm{mg} / \mathrm{kg})$ & $\mathrm{dC}$ & $\mathrm{cBC}^{* *}$ & $\mathrm{aA}^{* *}$ & $\mathrm{bB}^{* * *}$ & $\mathrm{dD}$ & $\mathrm{cC}^{* *}$ & $\mathrm{aA}^{* *}$ & $\mathrm{bB}^{* *}$ \\
\hline
\end{tabular}

Note: O (original meadow), $\mathrm{L}$ (lake dam), $\mathrm{C}$ (cropland), and $\mathrm{W}$ (woodland) in the table head were the four land-use patterns in Gudahu Wetland in Songnen Plain, China. BD, bulk density, M, moisture, EC, electrical conductivity, TOC, total organic carbon, TN, total N, AN, available N, TP, total P, AP, available $\mathrm{P}, \mathrm{TK}$, total $\mathrm{K}, \mathrm{AK}$, available K. Data represent means \pm standard deviation. The different lowercase letters represent significant differences $(P<0.05)$ and the different capital letters represent very significant differences $(P<0.01)$ between the sampling sites at the same sampling time using Duncan's multiple range test. T-test was used to evaluate the differences between different sampling times for the same sampling sites. ${ }^{*}$ represents significant differences $(P<0.05)$ and $* *$ represents significant differences $(P<0.01)$

\section{Sequencing of soil bacterial samples}

At the $97 \%$ similarity level, most bacterial samples' rarefaction curve tended to be flat (Fig. 1). It indicated that increased sequencing depth did not increase the number of new OTUs. The OTU coverage of the bacterial sample was close to saturation, and it 
could reflect the microbial community structure of the saline-alkaline soil samples. In general, the OTU numbers of $\mathrm{O}$ and $\mathrm{L}$ were lower than those of $\mathrm{C}$ and $\mathrm{W}$ in the dry season, but these OTU numbers gradually converged in the rainy season.
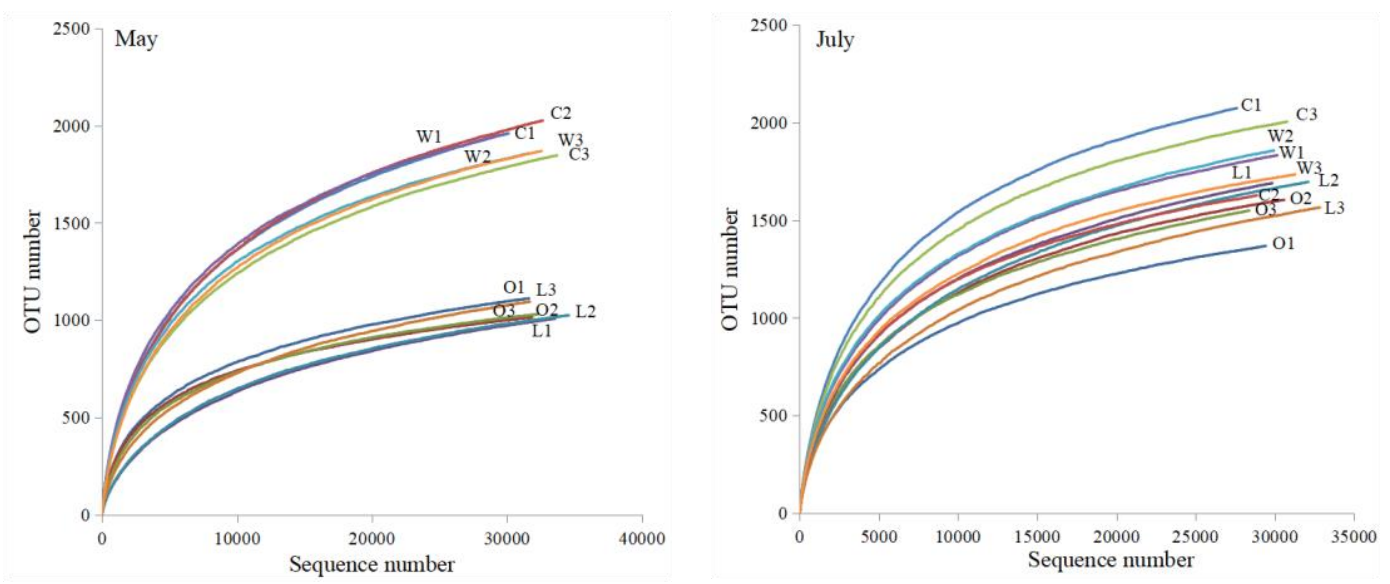

Figure 1. Rarefaction curve of bacterial soil samples at the $97 \%$ similarity level. Note: $O$ (original meadow), L (lake dam), C (cropland), and W (woodland) were the four land-use patterns in Gudahu Wetland in Songnen Plain, China

A total of 3,847 and 4,148 OTUs were observed in May and July, respectively (Fig. 2). A total of 3,489 core OTUs were found in May and July, which accounted for $90.69 \%$ and $84.11 \%$ of the total number of OTUs in May and July, respectively. At the two sampling times, there were 494 core OTUs in May and 707 in July. The OTU number of $\mathrm{C}$ was higher, and $\mathrm{O}$ was smallest than other land-use patterns, but the number of unique OTUs of $\mathrm{O}$ was the highest of all the land-use patterns.
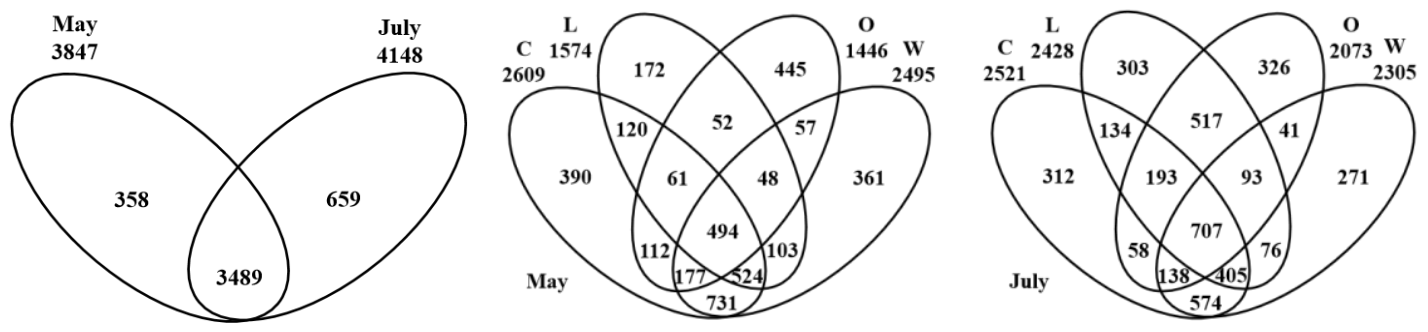

Figure 2. Venn diagram of OTU numbers of bacterial soil samples at the $97 \%$ similarity level. Note: $O$ (original meadow), $L$ (lake dam), $C$ (cropland), and $W$ (woodland) were the four landuse patterns in Gudahu Wetland in Songnen Plain, China

\section{Soil bacterial community structure}

As per the histogram representing the relative abundance of soil bacterial community compositions at the phyletic level (Fig. 3), 17 bacterial phyletic level groups (excluding groups with relative abundance $<0.5 \%$ ) were observed in May. With the highest relative abundance, Proteobacteria $(61.68 \%$ in $\mathrm{L}$ and $30.99 \%$ in C) was found to be the dominant soil bacterial group in May. The relative abundance of Acidobacteria in $\mathrm{C}$ was $18.28 \%$, and the lowest was $2.90 \%$ in L. The relative abundance of Chlorofloxi in L was 
$20.01 \%$, but only $4.93 \%$ in $\mathrm{O}$, and the relative abundance of Gemmatimonadetes in $\mathrm{O}$ was $18.27 \%$, lowest was $0.91 \%$ in $\mathrm{L}$.
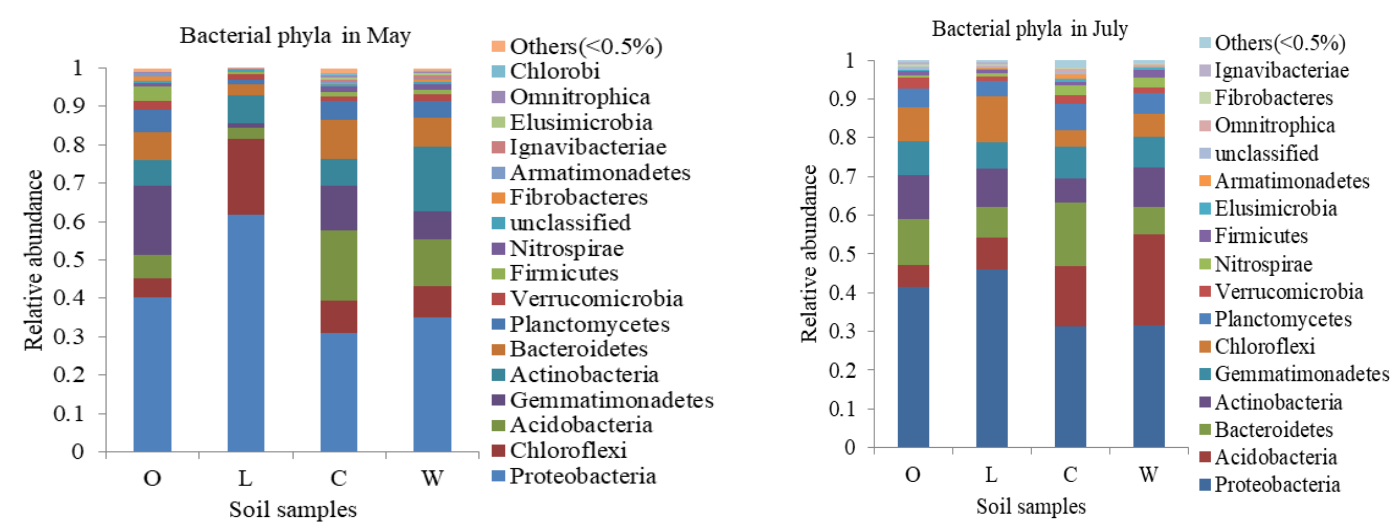

Figure 3. Soil bacterial community compositions at the phyletic level. Note: O (original meadow), L (lake dam), C (cropland), and W (woodland) were the four land-use patterns in Gudahu Wetland in Songnen Plain, China

A total of 16 phyletic level groups with relative abundance $>0.5 \%$ were observed in July. Proteobacteria was still the dominant group with a relative abundance of $45.86 \%$ in $\mathrm{L}$ and close to $31 \%$ in $\mathrm{C}$ and $\mathrm{W}$ (Fig. 3). The total relative abundance of Proteobacteria in July and May was not significantly $(P>0.05)$ different. The relative abundance of Acidobacteria in $\mathrm{W}$ was $23.51 \%$, very significantly $(P<0.01)$ higher than May, however, it was only $5.7 \%$ in $\mathrm{O}$. The relative abundance of Bacteroides in $\mathrm{C}$ was $16.41 \%$ and Actinobacteria in $\mathrm{L}, \mathrm{O}$, and $\mathrm{W}$ was around 10\%. In general, the top ten phyla with higher relative abundance in different seasons were the same, although the relative abundance was different.

A total of 21 and 36 generic level groups of soil bacteria (except those with relative abundance $<0.5 \%$ ) were observed in May and July, respectively, and a large number of unclassified groups were also observed (Fig. 4). In May, the number of unclassified genera in $\mathrm{C}$ reached $71.03 \%$ and $>50 \%$ in each soil type in July.
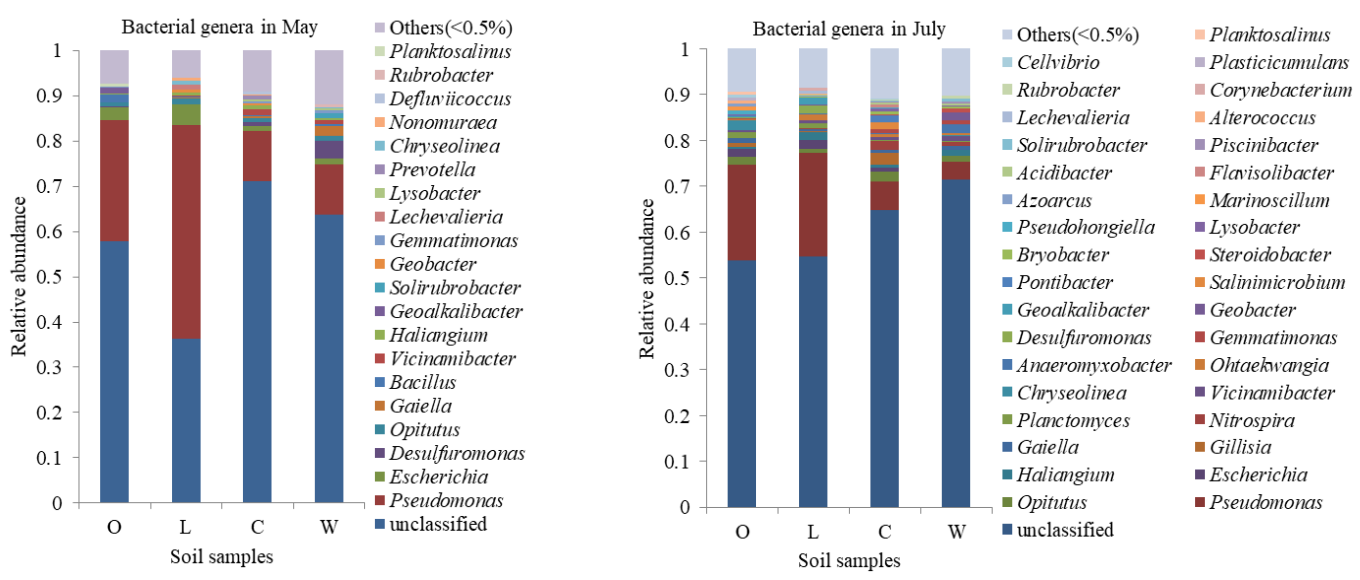

Figure 4. Soil bacterial community compositions at the generic level. Note: $O$ (original meadow), $L$ (lake dam), $C$ (cropland), and $W$ (woodland) were the four land-use patterns in Gudahu Wetland in Songnen Plain, China 
In May, Pseudomonas (47.43\% in L) belonging to Proteobacteria showed the highest relative abundance, followed by Escherichia (4.40\% in L), Desulfuromonas $(3.92 \%$ in W), and Opitutus (1.36\% in L). The relative abundance of Geoalkalibacter was $1.42 \%$ in $\mathrm{O}$, but $<0.1 \%$ in the other land-use patterns and Planktosalinus were found only in $\mathrm{O}$ $(0.58 \%)$.

In July also, Pseudomonas showed the highest relative abundance $(22.54 \%$ in $\mathrm{L}$ and $20.98 \%$ in O), followed by Opitutus (2.04\% in C), Escherichia (1.20\% in L), and Haliangium (1.70\% in L). The relative abundance of Geoalkalibacter was $1.39 \%$ in L, and Planktosalinus in $\mathrm{O}$ was more than $0.5 \%$, both of which were very low or absent in other soil types.

\section{Soil bacterial community diversity}

The bacterial community richness of $\mathrm{O}$ and $\mathrm{L}$, and the diversity of $\mathrm{L}$ in May were lower than that in July (Table 3). It suggested that the bacterial community of $\mathrm{O}$ and $\mathrm{L}$ were more sensitive to seasonal changes. In May, the richness of $\mathrm{O}$ and $\mathrm{L}$ was very significantly $(P<0.01)$ lower than that of $\mathrm{C}$ and $\mathrm{W}$, however, in July, this difference was not very significant $(0.01<P<0.05)$. In both seasons, the bacterial community diversity of $\mathrm{L}$ was the lowest, followed by $\mathrm{O}$, while that of $\mathrm{C}$ and $\mathrm{W}$ was higher.

Table 3. Bacterial community richness and diversity indexes of soil in Gudahu Wetland in Songnen Plain, China in May and July

\begin{tabular}{c|c|c|c|c}
\hline \multirow{2}{*}{ Type } & \multicolumn{2}{|c|}{ Chao1 index } & \multicolumn{2}{c}{ Shannon index } \\
\cline { 2 - 5 } & May & July & May & July \\
\hline O & $1334.33 \pm 107.93 \mathrm{bB}^{* *}$ & $1879.53 \pm 139.26 \mathrm{bA}^{* *}$ & $4.541 \pm 0.413 \mathrm{bB}$ & $5.268 \pm 0.346 \mathrm{bAB}$ \\
L & $1367.91 \pm 78.86 \mathrm{bB}^{* *}$ & $2071.02 \pm 54.24 \mathrm{abA}^{* *}$ & $3.357 \pm 0.660 \mathrm{cC}^{*}$ & $5.158 \pm 0.400 \mathrm{bB}^{*}$ \\
C & $2407.73 \pm 101.63 \mathrm{aA}$ & $2272.04 \pm 268.88 \mathrm{aA}$ & $5.786 \pm 0.110 \mathrm{aA}$ & $6.084 \pm 0.310 \mathrm{aA}$ \\
W & $2349.85 \pm 110.11 \mathrm{aA}$ & $2198.30 \pm 108.81 \mathrm{abA}$ & $5.801 \pm 0.301 \mathrm{aA}$ & $6.032 \pm 0.091 \mathrm{aAB}$ \\
\hline
\end{tabular}

Note: O (original meadow), L (lake dam), C (cropland), and $\mathrm{W}$ (woodland) in the table first column are the four land-use patterns in Gudahu Wetland in Songnen Plain, China. Data represent means \pm standard deviation. The different lowercase letters represent significant differences $(P<0.05)$ and the different capital letters represent very significant differences $(P<0.01)$ between the sampling sites at the same sampling time using Duncan's multiple range test. T-test was used to evaluate the differences between different sampling times for the same sampling sites. * represents significant differences $(P<0.05)$ and ** represents significant differences $(P<0.01)$

\section{Similarity analysis of bacterial community}

Based on the unweighted UniFrac algorithm, the bacterial community similarity of the four soil types in different seasons was determined at the OTU level. Out of the four land-use patterns, $\mathrm{O}$ was the first to be separated, which indicated that $\mathrm{O}$ was quite different from the others in terms of bacterial species composition (Fig. 5). Subsequently, L was separated, while $\mathrm{C}$ and $\mathrm{W}$ were the closest in bacterial species composition. It indicated that the bacterial community similarity of $\mathrm{C}$ and $\mathrm{W}$ was different from that of $\mathrm{O}$, besides, different land-use patterns in Gudahu Wetland altered the original bacterial community structure of the original meadow soil. 


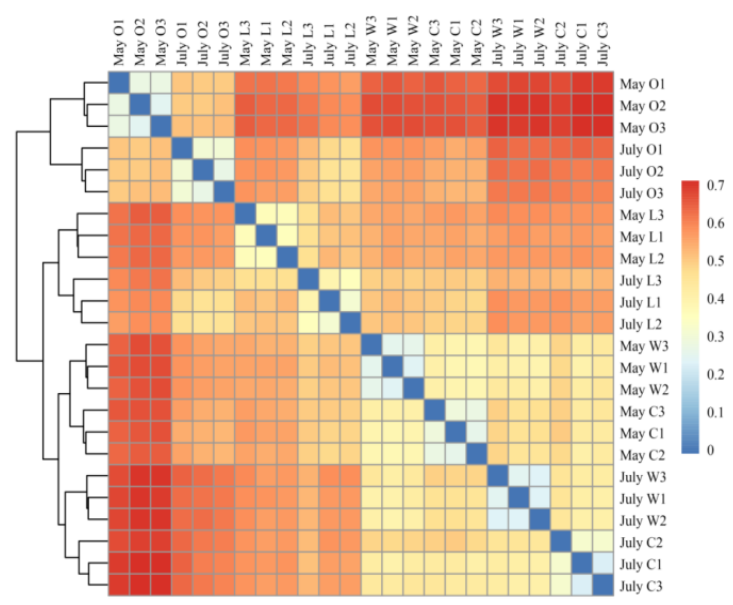

Figure 5. Heatmap of soil bacterial community similarity analysis based on the unweighted Unifrac algorithm. Note: $O$ (original meadow), L (lake dam), C (cropland), and W (woodland) were the four land-use patterns in Gudahu Wetland in Songnen Plain, China. Three soil samples were collected from each of these land-use patterns. The dark blue color indicates the small differences, while the deep red color indicates the low similarity

\section{Correlation between bacterial community and soil's physicochemical properties}

The RDA results were depicted in Fig. 6. The distance between $\mathrm{C}, \mathrm{W}$, and $\mathrm{O}$ on the first ordination axis was relatively low; however, L was separated from the other land-use patterns in May. C and $\mathrm{W}$ were close on the second ordination axis and were separated from $\mathrm{O}$. It indicated that the soil bacterial community of $\mathrm{C}$ and $\mathrm{W}$ was identical at the phyletic level, but remarkably different from $\mathrm{O}$ and L. In July, the four soil types were divided on the first two ordination axes, indicating the four soil types were different in the bacterial communities at the phyletic level.
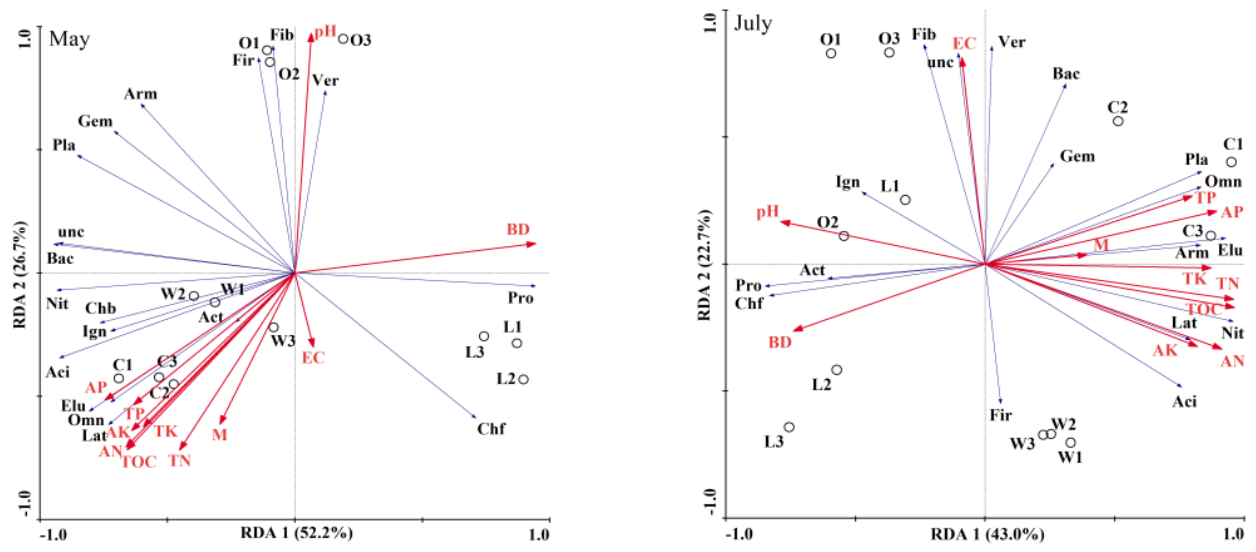

Figure 6. Redundancy analysis of bacterial communities (phyletic level) and soil's physiochemical properties. Note: O (original meadow), L (lake dam), C (cropland), and W (woodland) were the four land-use patterns in Gudahu Wetland in Songnen Plain, China. Three soil samples were collected from each of these land-use patterns. The abbreviation of bacterial phylum in this figure is the first three letters of Latin name in Figure 3, where Chf is

Chlorofloxi, Chb is Chlorobi, and unc is unclassified. BD, bulk density, M, moisture, EC, electrical conductivity, TOC, total organic carbon, $T N$, total $N, A N$, available $N, T P$, total $P, A P$, available $P, T K$, total $K, A K$, available $K$ 
At the phyletic level of bacteria, BD and $\mathrm{pH}$ were very significantly $(P<0.01)$ correlated to bacterial communities in May. A high correlation was observed between $\mathrm{BD}$ and $\mathrm{L}, \mathrm{pH}$ and $\mathrm{O}$. In July, $\mathrm{BD}, \mathrm{pH}$, and $\mathrm{EC}$ were very significantly $(P<0.01)$ correlated to bacterial communities. $\mathrm{BD}$ and $\mathrm{pH}$ had higher correlations with $\mathrm{O}$ and $\mathrm{L}$. Besides, EC was found to be correlated with $\mathrm{O}$. In general, $\mathrm{BD}, \mathrm{EC}$ and $\mathrm{pH}$ showed a higher impact on the bacterial communities of $\mathrm{O}$ and $\mathrm{L}$, while soil nutrients (TOC, TN, $\mathrm{AK}$, and so on) and $\mathrm{M}$ showed a higher impact on $\mathrm{C}$ and $\mathrm{W}$, but the impact was not statistically significant.

BD was negatively correlated with most bacterial phyla (Fig. 6). When integrated with Pearson correlation analysis outcomes between dominant phyla and soil's physicochemical properties (Table 4$), \mathrm{BD}$ showed a significant $(P<0.05)$ or very significant $(P<0.01)$ impact on phyla, such as Proteobacteria, Chlorofloxi. However, its impact differed with seasons. $\mathrm{M}$ and EC showed no significant $(P>0.05)$ effect on the dominant phyla except for Actinobacteria. However, $\mathrm{pH}$ showed a significant $(P<0.05)$ positive correlation with Gemmatimonades and Actinobacteria in different seasons. Except for Gemmatimonades, soil nutrients significantly $(P<0.05)$ affected bacterial phyla, such as Acidobacteria and Bacteroidetes (positive), or Chlorofloxi and Proteobacteria (negative). Out of the eleven soil physicochemical indexes analyzed in this study, soil nutrients remarkably impacted most of the bacterial phyla, especially on the rainy season, it showed the extensive impact. In contrast, $\mathrm{BD}, \mathrm{M}, \mathrm{EC}$ and $\mathrm{pH}$ primarily impacted individual dominant phylum to a different extent.

Table 4. Pearson correlation analysis between soil's physicochemical properties and top six soil bacterial phyla in Gudahu Wetland in Songnen Plain, China

\begin{tabular}{c|c|c|c|c|c|c|c|c|c|c|c|c}
\hline Season & Phylum & BD & M & EC & pH & TOC & TN & AN & TP & AP & TK & AK \\
\hline \multirow{5}{*}{ May } & Proteobacteria & $0.854^{* *}$ & - & + & - & - & - & - & - & $-0.602^{*}$ & - & - \\
& Chlorofloxi & $0.648^{*}$ & + & + & - & - & + & - & - & - & - & - \\
& Acidobacteria & $-0.928^{* *}$ & + & + & - & $0.867^{* * *}$ & $0.728^{* *}$ & $0.870^{* *}$ & $0.840^{* * *}$ & $0.924^{* *}$ & $0.830^{* *}$ & $0.867^{* *}$ \\
& Gemmatimonades & - & + & + & $0.662^{*}$ & - & - & - & + & + & + & + \\
& Actinobacteria & - & - & $-0.700^{*}$ & - & + & - & + & - & + & - & - \\
& Bacteroidetes & $-0.920^{* *}$ & + & + & + & + & + & + & $0.661^{*}$ & $0.734^{* *}$ & $0.597^{*}$ & $0.617^{*}$ \\
\hline \multirow{5}{*}{ July } & Proteobacteria & $0.673^{*}$ & - & + & + & $-0.751^{* *}$ & $-0.817^{* *}$ & $-0.741^{* *}$ & - & $-0.652^{*}$ & - & - \\
& Acidobacteria & - & + & - & - & $0.738^{* *}$ & $0.757^{* *}$ & $0.821^{* *}$ & + & + & + & $0.644^{*}$ \\
& Bacteroidetes & - & + & + & - & + & + & + & $0.667^{*}$ & $0.627^{*}$ & + & + \\
& Actinobacteria & - & $-0.641^{*}$ & - & $0.641^{*}$ & $-0.627^{*}$ & - & - & $-0.724^{* *}$ & $-0.685^{*}$ & $-0.661^{*}$ & $-0.613^{*}$ \\
& Gemmatimonades & - & - & + & + & + & + & + & + & + & + & - \\
& Chlorofloxi & $0.822^{* *}$ & - & - & + & $-0.748^{* *}$ & $-0.829^{* * *}$ & $-0.721^{* *}$ & $-0.625^{*}$ & $-0.765^{* * *}$ & $-0.654^{*}$ & - \\
\hline
\end{tabular}

Note: BD, bulk density, M, moisture, EC, electrical conductivity, TOC, total organic carbon, TN, total $\mathrm{N}$, AN, available N, TP, total P, AP, available P, TK, total K, AK, available K. The data in the table are correlation coefficients. * represents significant correlation $(P<0.05)$; ** represents very significant correlation $(P<0.01)$; + represents positive correlation and - represents negative correlation

\section{Discussion}

\section{Characteristics of soil bacterial community structure of Gudahu Wetland}

In this study, although the relative abundance of bacteria altered with seasons, Proteobacteria, Chlorofloxi, and Acidobacteria were highly dominant in the salinealkaline soil bacterial communities in the soil samples from Gudahu Wetland. These 
results were in line with Ma and Gong's (2013) study, except for the relative abundance of Firmicutes, which was relatively low. Proteobacteria have high adaptability and widely distributed across different environments. Besides, Proteobacteria play a crucial role in the ecosystem (Su et al., 2006; Zhao et al., 2018; Shao et al., 2019; Wang et al., 2020). In Gudahu Wetland's saline-alkaline soil, Proteobacteria showed the highest relative abundance in different seasons, demonstrating its high adaptability. Chlorofloxi is found in seafloor sediments, temperate grasslands, and alpine meadows (Krzmarzick et al., 2012). Hug et al. (2013) reported that Chloroflexi was the most abundant and highly diverse in the aquifer sediments. In this study, the relative abundance of Chlorofloxi in L was relatively high, which might be related to the excavation of soil from the lake during the dam construction. Acidobacteria, commonly occurring phylum in the natural environment (Dedysh and Damsté, 2018), is actively involved in the degradation of plant cellulose and other macromolecular polymers. However, species occurring in this phylum are difficult to culture (Wei et al., 2018). In this study, Acidobacteria in $\mathrm{C}$ and $\mathrm{W}$ showed high relative abundance, which might be correlated to the accumulation of a high amount of cellulose in plant litter, such as straw and leaves.

As per a previous study, many unclassified genera are present in saline-alkaline wetland soil (Liu et al., 2016). Similar observations were made in this study as well. It indicated that saline-alkaline wetland soil could be a potential source of novel species. Besides, Pseudomonas, which is a widely occurring bacteria in soil and actively involved in removing environmental pollutants (Kimura et al., 2018; Wang et al., 2019), showed the higheat relative abundance in this study. Geoalkalibacter were isolated from soda lakes and were identified as a potential alkaliphilic representative (Zavarzina et al., 2006). In this study, Geoalkalibacter were found in O and L of Gudahu Wetland. Planktosalinus of Bacteroidetes were found in Xiaochaidan salt lake in Qaidam Basin in China (Zhong et al., 2016), which could also be considered a representative group of $\mathrm{O}$ in Gudahu Wetland. Planktosalinus showed a relative abundance of $0.5 \%$ in $\mathrm{O}$.

\section{Factors impacting the bacterial communities of Gudahu Wetland soil}

Soil microbial community structure and diversity exhibit seasonal variations (Zhao et al., 2018; Yang et al., 2020). Zhang and Feng (2008) proposed that the number of saline-alkaline soil microbiota in Songnen Plain increased with increasing temperature. In this study, the total OTU numbers of the four soil types in May were lower than those in July. The bacterial community richness of $\mathrm{O}$ and $\mathrm{L}$, and the diversity of $\mathrm{L}$ increased significantly, with the changes in season, however, $\mathrm{C}$ and $\mathrm{W}$ did not show any significant changes. It showed that altered soil bacterial communities of $\mathrm{O}$ and $\mathrm{L}$ were remarkably affected by seasonal changes.

The land-use pattern is crucial factor in determining the microbial community composition of wetland soil (Pei et al., 2009; Chi et al., 2018). Apart from O, human disturbances affected L, C, and W soil types in Gudahu Wetland differently in different periods. Cultivation and fertilization had remarkable effects on $\mathrm{C}$. When soil nutrient content was high, the bacterial OTU number was the highest, and the richness and diversity of the bacterial community were relatively higher. Besides, afforestation improves microbial diversity (Qin et al., 2017). In this study, the bacterial community of $\mathrm{W}$ was similar to that of $\mathrm{C}$ but more diverse than $\mathrm{O}$ and $\mathrm{L}$.

Saline-alkaline soil is generally afflicted with degradation, and plant diversity associated with different land-use patterns substantially affects the degradation process 
of soil (Peng et al., 2017). In C, cultivation and fertilization increased the nutrient content, but reduced plant diversity, also, afforestation increased plant diversity and soil fertility, but dam construction reduced soil fertility and altered soil texture. O had the lowest bacterial OTUs, and the highest number of unique OTUs, besides, its bacterial community was significantly different from the other three soil types. It showed that artificial disturbance, dam construction, cultivation, and afforestation altered the original meadow's soil bacterial community in Gudahu Wetland.

The physicochemical properties of saline-alkaline wetland soil affected soil microbial composition and diversity (Niu et al., 2017). In this study, BD, M, EC and pH had significant effects on individual dominant bacterial phyla. Soil $\mathrm{pH}$ significantly impacts the diversity of soil microbial communities (Shen et al., 2013; Li et al., 2018c; Fan and $\mathrm{Wu}, 2020)$. High $\mathrm{pH}$ generally decreases the diversity of soil microbial communities (Zhang and Feng, 2008; Chu et al., 2017). Wang et al. (2020) reported that soil EC is a key factor that drives the composition of the bacterial community under alkaline conditions in the saline-alkaline soil of Songnen Plain. This study also showed that $\mathrm{pH}$ and EC significantly affected bacterial communities, especially in $\mathrm{O}$ and $\mathrm{L}$. At the phyletic level, $\mathrm{pH}$ significantly affected Gemmatimonadetes and Actinobacteria, while EC significantly affected only Actinobacteria, in contrast, to the previous study by Canfora et al. (2014). The influence of soil moisture on microorganisms was also very significant. Soil moisture can regulate the soil's oxygen content, and regulate the type, activity, and growth of microbes in the soil. Furthermore, excessively high or low water content found to be detrimental for bacterial growth (Yan et al., 2015; Zhang et al., 2016; Zou et al., 2018). However, in this study, the Gudahu Wetland soil had a low $M$ with no significant seasonal changes. Besides, no significant differences were observed between $\mathrm{O}$ and $\mathrm{W}$. Apart from Actinobacteria, $\mathrm{M}$ had no significant impact on the bacterial community at the phyletic level. Soil nutrients showed significant effects on bacterial communities (Hansel et al., 2008). In this study, soil nutrients affected multiple bacterial phyla, especially in the rainy season, but the impact was not significant as that of $\mathrm{BD}, \mathrm{pH}$, and $\mathrm{EC}$. Li et al. (2018b) showed that the relative abundance of Actinobacteria was negatively correlated to AP and AK, and the impact was significant in July, in line with the outcomes of this study. Concurrently, Li et al. (2018b) showed that AN and AP did not significantly affect Proteobacteria, whereas AK significantly influenced Chlorofloxi, not in line with the current study.

\section{Suggestions for rational land-use}

Saline-alkaline soil is ecologically fragile and prone to further degradation (Zhang and Feng, 2008). Vegetation restoration can not only improve the quality of saline-alkaline soil (Ravindran et al., 2007), but also improve the degraded wetland soil environment and improve the diversity of plants and soil microbes (Shao et al., 2019). In the process of returning farmland to wetland around Gudahu Wetland, we should not only consider the physicochemical properties of the soil, but also refer to the differences in soil microbial community structure, which has an important significance in guiding the choice of the plants used to return farmland to wetland. This study on the structure and diversity of soil bacterial communities of four land-use patterns showed that the bacterial community of $\mathrm{C}$ was similar to that of $\mathrm{W}$, but different from that of $\mathrm{O}$. Afforestation improves soil microbial diversity and soil fertility (Kaiser et al., 2016; Qin et al., 2017; Yang et al., 2019), and restore saline-alkaline soil ecology (Zhang et al., 2005). Thus, to protect the biodiversity of wetland and return farmland to wetland 
effectively, we suggest that trees should be planted in the cropland and lake dam, to increase the woodland area. It will prevent the gradual degradation of the saline-alkaline soil, and enhance the ecological and economic benefits.

\section{Conclusion}

Proteobacteria was the dominant bacterial phylum of Gudahu saline-alkaline wetland soil in the dry and rainy seasons. Numerous unclassified genera were observed in the soil samples of Gudahu Wetland, which indicates that it is a potential source for new bacterial species. The bacterial community diversity of cropland and woodland was higher than the original meadow, the lowest diversity found in the lake dam soil. Dam construction, agriculture and forestry changed the structure and diversity of the original meadow's soil bacterial community, and agriculture and forestry had a more significant influence than dam construction. BD, EC and $\mathrm{pH}$ had significant effects on the soil bacterial community, especially that of the original meadow and lake dam. Soil nutrients (TOC, TN, AK, and so on) and $\mathrm{M}$ had no significant effect on the soil bacterial community, particularly in cropland and woodland. BD, M, EC and $\mathrm{pH}$ showed significant effects on individual dominant phyla, whereas soil nutrients had more extensive effects on dominant phyla. Different land-use patterns altered the physicochemical properties of saline-alkaline soil and affected the soil bacterial community's structure and diversity. Based on the outcomes of the current study, we suggest that afforestation of cropland and lake dam areas can effectively return farmland to wetland in Gudahu Wetland and prevent the degradation of the saline-alkaline soil of Songnen Plain. Our future studies will focus on microbial function in saline-alkaline soil, to improve the microbial application to prevent and control soil degradation in the saline-alkaline wetland.

Acknowledgements. This work was funded by Teaching Reform Project of Higher Education in Heilongjiang Province [SJGZ20190034], Heilongjiang Province Key Laboratory of Cold Region Wetland Ecology and Environment Research Laboratory Open Project [201905], Heilongjiang Province Key Laboratory of Cold Region Wetland Ecology and Environment Research Laboratory Open Project [201906], National Natural Science Foundation of China [41977095] and China-Norway International Collaboration Project "Sinagrain II" [CHN-17/0019].

\section{REFERENCES}

[1] Bao, S. (2007): Soil Agro-chemistrical Analysis, $3^{\text {rd }}$ ed. - China Agriculture Press, Beijing.

[2] Bian, J., Tang, J., Lin, N. (2008): Relationship between saline-alkali soil formation and neotectonic movement in Songnen Plain, China. - Environmental Geology (Berlin) 55(7): 1421-1429.

[3] Canfora, L., Bacci, G., Pinzari, F., Papa, G. L., Dazzi, C., Benedetti, A. (2014): Salinity and bacterial diversity: to what extent does the concentration of salt affect the bacterial community in a saline soil? - Plos One 9(9): 1-15.

[4] Caporaso, J. G., Kuczynski, J., Stombaugh, J., Bittinger, K., Bushman, F. D., Costello, E. K., Fierer, N., Peña, A. G., Goodrich, J. K., Gordon, J. I., Huttley, G. A., Kelley, S. T., Knights, D., Koenig, J. E., Ley, R. E., Lozupone, C. A., McDonald, D., Muegge, B. D., Pirrung, M., Reeder, J., Sevinsky, J. R., Turnbaugh, P. J., Walters, W. A., Widmann, J., Yatsunenko, T., Zaneveld, J., Knight, R. (2010): QIIME allows analysis of high-throughput community sequencing data. - Nature Methods 7(5): 335-336. 
[5] Chen, H. (2018): Generate high-resolution Venn and Euler plots. - URL https://CRAN.Rproject.org/package $=$ VennDiagram.

[6] Chi, Q., Wu, D., Wang, Y., Sun, G. (2018): Research on soil microbial community structure of different forest-wetland ecotones in Xiaoxing'an Mountain. - Forest Engineering 34(3): 6-13, 18.

[7] Chu, H., Wang, Y., Shi, Y., Lv, X., Zhu, Y., Han, X. (2017): Current status and development trend of soil microbial biogeography. - Bulletin of Chinese Academy Sciences 32(6): 585-592.

[8] Dedysh, S. N., Damsté, J. S. S. (2018): Acidobacteria. - John Wiley \& Sons, Ltd., Hoboken.

[9] Deng, J., Zhu, W., Zhou, Y., Yin, Y., Bai, X., Zhang, H., Zhang, Y., Qin, S. (2018): Effects of different land use patterns on the soil microbial community diversity in montane region of eastern Liaoning Province, China. - Chinese Journal of Applied Ecology 29(7): 22692276.

[10] Edgar, R. C. (2013): UPARSE: highly accurate OTU sequences from microbial ampliconreads. - Nature Methods 10: 996-998.

[11] Fan, W., Wu, J. (2020): Short-term effects of returning granulated straw on soil microbial community and organic carbon fractions in dryland farming. - The Journal of Microbiology 58(8): 657-667.

[12] Foti, M., Sorokin, D. Y., Lomans, B., Mussman, M., Zacharova, E. E., Pimenov, N., Kuenen, J. G., Muyzr, G. (2007): Diversity, activity, and abundance of sulfate-reducing bacteria in saline and hypersaline soda lakes. - Applied \& Environmental Microbiology 73(7): 2093-2100.

[13] Gandhi, J. K., Tatu, K., Kamboj, R. D. (2018): A review of studies on bacterial and fungal diversity in wetland ecosystems. - Research \& Reviews: A Journal of Microbiology and Virology 8(1): 25-38.

[14] Griffiths, B. S., Laurent, P. (2013): Insights into the resistance and resilience of the soil microbial community. - FEMS Microbiology Reviews 37(2): 112-129.

[15] Hansel, C. M., Fendorf, S., Jardine, P. M., Francis, C. A. (2008): Changes in bacterial and archaeal community structure and functional diversity along a geochemically variable soil profile. - Applied and Environmental Microbiology 74(5): 1620-1633.

[16] Hug, L. A., Castelle, C. J., Wrighton, K. C., Thomsa, B. C., Sharon, I., Frischkorn, K. R., Williams, K. H., Trige, S. G., Banfied, J. F. (2013): Community genomic analyses constrain the distribution of metabolic traits across the Chloroflexi phylum and indicate roles in sediment carbon cycling. - Microbiome 1(1): 22.

[17] Jin, Y., Wu, Z., Tan, F., Zhang, Y. (2017): Study on functional diversity of soil microorganism in different mangrove plants based on Biolog-Eco Technology. - Ecology and Environmental Sciences 26(8): 1292-1300.

[18] Kaiser, K., Wemheuer, B., Korolkow, V., Wemheuer, F., Nacke, H., Schöning, I., Schrumpf, M., Daniel, R. (2016): Driving forces of soil bacterial community structure, diversity, and function in temperate grasslands and forests. - Scientific Reports 6(1): 33696.

[19] Kimura, N., Watanabe, T., Suenaga, H., Fujihara, H., Futagami, T., Goto, M., Hanada, S., Hirose, L. (2018): Pseudomonas furukawaii sp. nov. a polychlorinated biphenyl-degrading bacterium isolated from biphenyl-contaminated soil in Japan. - International Journal of Systematic and Evolutionary Microbiology 68(5): 1429-1435.

[20] Kolde, R. (2019): pheatmap: Pretty Heatmaps. - URL https://CRAN.Rproject.org/package=pheatmap.

[21] Krzmarzick, M. J., Crary, B. B., Harding, J. J., Oyerinde, O. O., Leri, A. C., Myneni, S. C. B., Novak, P. J. (2012): Natural niche for organohalide - respiring Chloroflexi. - Applied \& Environmental Microbiology 78(2): 393-401.

[22] Li, Y., Yang, X., Qin, L., Lv, G., He, X., Zhang, X. (2018a): The bacterial diversity and community structures in rhizosphere soil of two halophytes, Lycium ruthenicum and Kalidium capsicum. - Acta Ecologica Sinica 38(9): 3118-3131. 
[23] Li, J., Hou, H., Wang, C., Zhang, S., Ma, J., Ding, Z., Huang, L., Dong, J., Yang, Y. (2018b): Soil bacteria diversity of reclaimed soil based on High Throughput Sequencing. Environmental Science \& Technology 41(12): 148-157.

[24] Li, S., Ma, D., Zang, S., Wang, L., Sun, H. (2018c): Structural and functional characteristics of soil microbial community in the Songjiang wetland under different interferences. - Acta Ecologica Sinica 38(22): 7979-7989.

[25] Liu, B., Yuan, J., Yiu, S., Li, Z., Xie, Y., Chen, Y., Shi, Y., Zhang, H., Li, Y., Lam, T., Luo, R. (2012): COPE: an accurate $k$-mer-based pair-end reads connection tool to facilitate genome assembly. - Bioinformatics 28(22): 2870-2874.

[26] Liu, W., Zhang, W., Liu, G., Zhang, Y., Zhang, G. (2016): Microbial diversity in the salinealkali soil of a coastal Tamarix chinensis woodland at Bohai bay, China. - Journal of Arid Land 8(2): 284-292.

[27] Liu, F., Mo, X., Kong, W., Song, Y. (2020): Soil bacterial diversity, structure, and function of Suaeda salsa in rhizosphere and non-rhizosphere soils in various habitats in the Yellow River Delta, China. - Science of The Total Environment 740: 140144.

[28] Ma, B., Gong, J. (2013): A meta-analysis of the publicly available bacterial and archaeal sequence diversity in saline soils. - World Journal of Microbiology and Biotechnology 29(12): 2325-2334.

[29] Niu, S., Long, Y., Li, Y., Da, W., Hu, S., Li, W., Zhu, X., Kong, W. (2017): Microbial diversity in saline alkali soil from Hexi Corridor analyzed by Illumina MiSeq Highthroughput Sequencing system. - Microbiology China 44(9): 2067-2078.

[30] Pei, X., Xu, Y., Wei, W. (2009): A Review on soil microorganisms in wetland ecosystem. Wetland Science 7(2): 181-186.

[31] Peng, M., Jia, H., Wang, Q. (2017): The effect of land use on bacterial communities in saline-alkali soil. - Current Microbiology 74(3): 325-333.

[32] Qin, H., Li, C., Ren, Q. (2017): Effects of different land use patterns on soil bacterial and fungal biodiversity in the hydro-fluctuation zone of the Three Gorges Reservoir region. Acta Ecologica Sinica 37(10): 3494-3504.

[33] R Core Team. (2017): R: A language and environment for statistical computing. - R Foundation for Statistical Computing, Vienna, Austria. URL http://www.R-project.org/.

[34] Ravindran, K. C., Venkatesan, K., Balakrishnan, V. (2007): Restoration of saline land by halophytes for Indian soils. - Soil Biology and Biochemistry 39(10): 2661-2664.

[35] Shang, Z., Gao, Q., Dong, M. (2003): Impacts of grazing on the alkalinized-salinized meadow steppe ecosystem in the Songnen Plain, China - a simulation study. - Plant and Soil 249(2): 237-251.

[36] Shao, Y., Cao, S., Liu, C., Luo, M. (2019): Bacterial diversity in soils of Nanniwan wetland based on high-through put sequencing. - Journal of Arid Land Resources and Environment 33(2): 158-163.

[37] Shen, C., Xiong, J., Zhang, H., Feng, Y., Lin, X., Li, X., Liang, W., Chu, H. (2013): Soil $\mathrm{pH}$ drives the spatial distribution of bacterial communities along elevation on Changbai Mountain. - Soil Biology \& Biochemistry 57: 204-211.

[38] Su, Y., Li, H., Li, J., Yu, Y., Chen, B. (2006): Investigation on bacterial diversity of deepsea sediments from Pacific Arctic. - Chinese High Technology Letters 16(7): 752-756.

[39] Wan, Z., Yu, S., Wang, H., Sun, G. (2003): The types and characteristics of inland salinealkaline wetland in Songnen Plain. - Wetland Science 1(2): 141-146.

[40] Wang, L., Seki, K., Miyazaki, T., Ishihama, Y. (2009): The causes of soil alkalinization in the Songnen Plain of Northeast China. - Paddy and Water Environment 7(3): 259-270.

[41] Wang, M., Wang, Z., Yu, L., Zhang, C., Bi, J., Sun, J. (2019): Pseudomonas qingdaonensis sp. nov., an aflatoxin-degrading bacterium, isolated from peanut rhizospheric soil. Archives of Microbiology 201(5): 673-678.

[42] Wang, S., Sun, L., Ling, N., Zhu, C., Chi, F., Li, W., Hao, X., Zhang, W., Bian, J., Chen, L., Wei, D. (2020): Exploring soil factors determining composition and structure of the 
bacterial communities in saline-alkali soils of Songnen Plain. - Frontiers in Microbiology 10: 2902.

[43] Wei, Z., Li, Y., Jiang, W., Liao, X. (2018): Diversity of Acidobacteria in rhizosphere soils of common trees in Wuxi. - Chinese Journal of Ecology 37(9): 2649-2656.

[44] Wu, Z., Raven, P. H., Hong, D. (2013): Flora of China. - Science Press, Beijing.

[45] Yan, N., Marschner, P., Cao, W., Zuo, C., Qin, W. (2015): Influence of salinity and water content on soil microorganisms. - International Soil and Water Conservation Research 3(4): 316-323.

[46] Yang, W., Ren, Q., Li, C., Song, H., Yuan, Z., Ma, W., Cui, Y., Wang, C. (2019): Dynamic changes in soil microbial biomass carbon, nitrogen and phosphorus of Taxodium distichum and Salix matsudana plantation in the hydro-fluctuation belt of the Three Gorges Reservoir Region. - Acta Ecologica Sinica 39(5): 1496-1506.

[47] Yang, Z., Wang, Y., Wu, Z., Ren, L., Ma, Y. (2020): Microbial community structure and seasonal variations in mudflat sediments of Sansha Bay, China. - Applied Ecology and Environmental Research 18(1): 987-1000.

[48] Yu, S., Shi, C., Hu, B., Ding, J., Meng, B., Yang, C. (2020): Analysis of microbial community structure and diversity of saline soil in Gudahu Wetland. - Acta Ecologica Sinica 40(11): 3764-3775.

[49] Zak, D. R., Holmes, W. E., White, D. C., Peacock, A. D., Tilman, D. (2003): Plant diversity, soil microbial communities, and ecosystem function: are there any links? Ecology 84(8): 2042-2050.

[50] Zavarzina, D. G., Kolganova, T. V., Boulygina, E. S., Kostrikina, N. A., Tourova, T. P., Zavarzin, G. A. (2006): Geoalkalibacter ferrihydriticus gen. nov. sp. nov. the first alkaliphilic representative of the family Geobacteraceae, isolated from a soda lake. Microbiology 75(6): 673-682.

[51] Zhang, J., Zhang, X., Zhou, J., Liu, G., Li, D. (2005): World resources of saline soil and main amelioration measures. - Research of Soil and Water Conservation 12(6): 28-31.

[52] Zhang, W., Feng, Y. (2008): Distribution of soil microorganism and their relations with soil factors of saline-alkaline grasslands in Songnen Plain. - Grassland and Turf 3: 7-11.

[53] Zhang, Q., Huang, X., Guo, X. (2016): Analysis of the characteristics of rhizosphere bacterial diversity from plants with different water level gradients based on T-RFLP. - Acta Ecologica Sinica 36(14): 4518-4530.

[54] Zhang, Q., Wakelin, S. A., Liang, Y., Chu, G. (2018): Soil microbial activity and community structure as affected by exposure to chloride and chloride-sulfate salts. Journal of Arid Land 10(5): 737-749.

[55] Zhao, C., Xie, H., Xu, J., Xu, X., Zhang, J., Hu, Z., Liu, C., Liang, S., Wang, Q., Wang, J. (2015): Bacterial community variation and microbial mechanism of triclosan (tcs) removal by constructed wetlands with different types of plants. - Science of The Total Environment 505: 633-639.

[56] Zhao, M., Yin, C., Li, C., Zhong, S., Yu, K., Fang, S. (2018): Using Miseq sequencing to analyze seasonal soil microbial community dynamics in reclaimed Scirpus mariqueter coastal wetlands. - Journal of Shanghai Ocean University 27(5): 718-727.

[57] Zhong, Z., Liu, Y., Wang, F., Zhou, Y., Liu, H., Liu, Q., Liu, Z. (2016): Planktosalinus lacus gen. nov., sp. nov., a member of the family Flavobacteriaceae isolated from a salt lake. - International Journal of Systematic and Evolutionary Microbiology 66(5): 20842089.

[58] Zhou, D., Li, Q., Song, Y., Wang, X. (2011): Salinizaion-alkalization of Leymus chinensis glassland in Songnen Plain of Northeast China. - Chinese Journal of Applied Ecology 22: 1423-1430.

[59] Zou, F., Wu, X., Zhang, W., Ma, Y., Liu, Y., Wu, L. (2018): Responses of soil microbial functional traits to seasonal water level changes in a typical wetland of the Poyang Lake. Acta Ecologica Sinica 38(11): 3838-3847. 